\title{
Alternative Energy Sources for Energy Crisis: Rethinking the Global and Bangladesh Perspectives
}

\author{
Md. Shafiqul Islam
}

Department of Nuclear Engineering, University of Dhaka, Dhaka-1000, Bangladesh

\begin{abstract}
This paper discusses the evolution of various energy resources, their reserves, and usages for policy makers and energy experts. It finds that there is a huge supply-side deficit to meet the demand of the 7 billion people in today's world. To meet this huge energy needs, alternative energy sources are investigated and suggestions are made to address energy crises in Bangladesh and global contexts. The author argues that with the advancement of technology, a completely new nuclear meaning thorium reactors, small modular reactors, and novel solar technologies can offer potential alternatives to meet the needs of mankind. In addition, developing cost-effective carbon capture storage devices to catch carbon at its generating sources, energy storage devices, and energy culture model can be explored. The search for alternative technologies and energy culture require robust discussion, cooperation, and investment in clean energy sources. The paper concludes with a discussion of future energy policy and appropriate action plans to adopt emerging alternative technologies as per the promises made at the Paris Climate Change Accord COP21.
\end{abstract}

Keywords: Energy resources, Alternative technology, Energy culture model, Energy Cooperation.

\section{INTRODUCTION}

Energy means the ability to perform useful work. It has different forms, i.e., light, thermal, chemical, mechanical, electrical, nuclear and the like. Discovery of fire by rubbing stones a million years ago during the early Stone Age is the thermal form of energy. This was the only knowledge for human ancestors to make a fire but they did not have fire making skills. Scientists have speculated that discovery of fire was a major turning point in human evolution. Based on energy conversions in different forms and their developments, human civilization was made. Now without useful energy, modern life would cease to exist. Wood was the first and foremost of human history, the primary source of energy [1]. It was readily available. Certain other energy sources found only in localized areas, were also used in ancient times; natural peat, natural wood charcoal, and coal from surface deposits and oil from seepages of underground deposits [1]. This situation changed when wood began to be used during the Middle Ages to make charcoal [1]. The charcoal was heated with metal ore to break up chemical compounds and free the metal. As forests were cut and wood supplies dwindled at the onset of the industrial revolution in the mid- $18^{\text {th }}$ century, charcoal was replaced by coal in the reduction of ores [1]. Coal, which began to be used to drive steam engines (1776), became the dominant energy source as the industrial revolution proceeded [2]. Automobiles were introduced around $19^{\text {th }}$ century converting the transportation fuel

*Address correspondence to this author at the Department of Nuclear Engineering, University of Dhaka, Dhaka-1000, Curzon Hall, Bangladesh; Tel: +880-2-9661900; Fax: +880-2-9667222; E-mail: msislam@du.ac.bd from hay and oats to oil. Then people began heating their homes with coal and oil instead of wood [3]. Naturally occurring gas $\left(\mathrm{CH}_{4}\right)$ was suddenly discovered and started using to light houses and streetlights. Martin H. Klaproth discovered uranium in 1789 during analyzing unknown mineral samples 'pitchblende' [4]. Uranium was not used as fuels before the discovery of fission reaction. All these fossil fuels are finite. Estimates suggest that some fossil fuels mainly natural gas and oil may run out during this century [5]. Nuclear energy held great promise, but TMI, Chernobyl and Fukushima disasters, as well as atomic bombs, convinced many people that nuclear energy was too dangerous. Since supplies are finite but demand has been growing exponentially specially in the developing countries (China. India, Africa, the Middle East, and Southeast Asia). Still in the modern age or the technologically advanced world of today, there is a huge energy crisis in the Africa and Asian regions [6]. Governments of those regions are increasingly under pressure to ensure a reliable electricity supply to all people. It can be mentioned the landmark ruling on 10 October 2013 that the Madras High Court declared electricity supply is a legal right and its denial is a violation of human rights [7].

Within the year 2020, world's population will cross the mark 8 billion, and they will need about $2,63,700$ TWh of fuel which is double of today's demand. Furthermore, without using energy-efficient technologies and widespread deployment of $\mathrm{CO}_{2}$ capture storage devices, $\mathrm{CO}_{2}$ emissions will increase at least 50 percent higher. In reality, there won't be enough supply of fuel with the traditional energy sources to meet the enormous demand for fuel. 
Alternative energy will be the key for the future generation to live by providing cheap $\mathrm{CO}_{2}$ free energy, energy cheaper than they can get by burning coal. Nobel laureate scientist Rubbia $C$. has stated that per capita power consumption of the advanced countries people has increased about 100 times from the beginning of the industrial revolution as shown in Figure 1. The daily emission rate of $\mathrm{CO}_{2}$ per person is about $100 \mathrm{~kg}$ from billion tonnes of $\mathrm{CO}_{2}$ emissions come out a year from burning the fossil fuels in the modern world. The longevity of the survival of the necessarily limited fossil's era will be affected by the discovery of new and exploitable resources, inevitable growth of the world's population and their standard of living. If these factors are hard to assess, taking long lead time for massive development of some new energy sources, the end of the cheap and abundant fossils may be at sight.

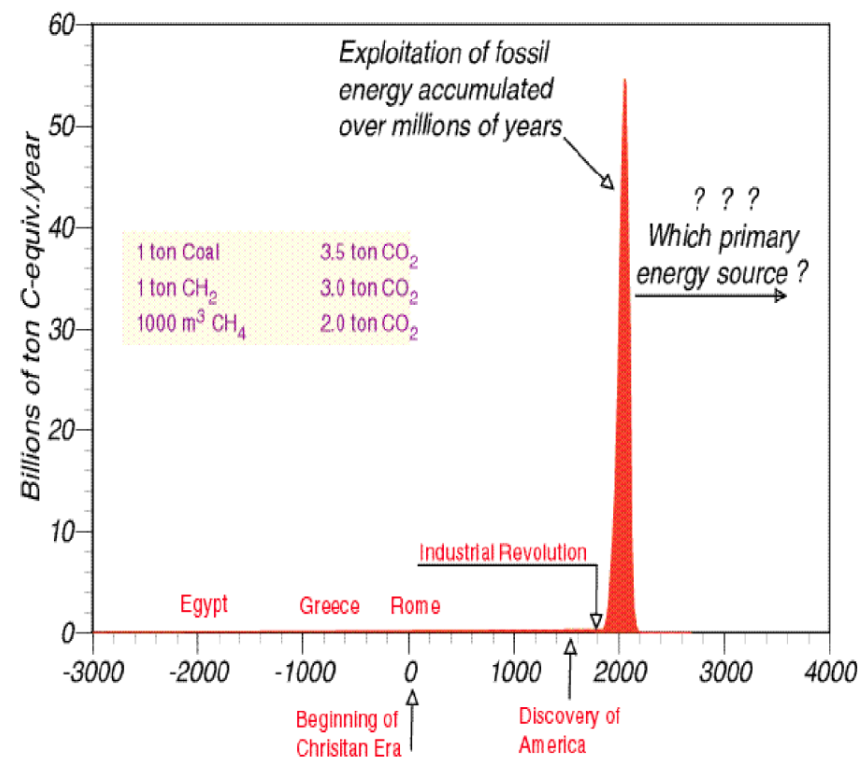

Figure 1: Exploitation of fossil fuels accumulated over millions of years [5].

For this, new dominant energy sources with an acceptable climatic impact are urgently required in order to meet the huge energy demands specially. On 30 November 2015, in the week-long Paris climate change conference COP21, the world's leaders have aimed to keep the global warming well below $2^{\circ} \mathrm{C}$ above the pre-industrial levels within the next 15 years, and 195 countries have promised the climate change agreements to set their individual action plan [8]. If this agreement would turn into reality, the world needs to find alternatives to coal and oil. It is, therefore, what are the sources of alternative energy? Can nuclear or renewables mainly solar be a source of alternative energy? The likely answers to this question are given in
Section 4. The objective of this paper is to provide a brief summary of global and Bangladesh energy crisis based on available resources and usages and of possible paths to the future.

Section 2 describes the methodology of the study. Section 3 enumerates the chronicle of the global energy crisis. Section 4 limits on some suggestions to get rid of the global energy crisis. Section 5 houses the Bangladesh's energy policy, necessity for power sector reforms, available energy resources and limitations, and perspective energy plan. Section 6 provides some suggestions for getting rid of Bangladesh's energy crisis. Section 7 draws an overall conclusion. Finally, Section 8 recommends the development of an energy culture model to raise awareness of the people.

\section{METHODOLOGY}

The study has been carried out on the basis of the information from relevant secondary sources, such as world energy outlook, textbooks, journals, conference proceedings, Article published in the newspapers, printed materials, internet and online publications. The review of existing literature allows the author to investigate the energy evolutions. The main areas include biomass and fossil fuels (coal, oil, gas), energyuse pattern in the preindustrial and industrial ages, climate changes due to dominant use of fossil fuels, R\&D activities related to technology innovations for energy generations and storages from alternative sources. However, the analysis, interpretation, and comments are entirely the author's own.

\section{REASONS FOR GLOBAL ENERGY CRISIS}

Energy crisis is the most discussed issue in today's world. The repetitive increase in oil price has left the world tumultuous. However, if we look back, the cost of every barrel of oil in the international market was below 25 dollars until 2003, despite the energy crisis. In a mere span of just four years, it increased to about a hundred dollars without any incidents. On $14^{\text {th }}$ July 2008, the price of oil was on the brim of 150 dollars, which was the reason for the poor economy throughout the world. Hundreds of thousands of people had started protesting to bring down the cost. The constant increase had caused obstructions in general people's daily lives. However, protests and vandalisms are no solutions to the energy crisis.

Energy resources, usages and crisis have been the long and the most discussed topics since human 
civilization. A substance when undergoes a chemical or nuclear reaction that produces useful energy is known as a fuel. Ever since the discovery of fire, mankind has commenced the use of fuels. Back then, fuels were mainly used for heating and cooking purposes. Then with the growth of human civilization, Homo sapiens came across all sorts of different fuels, which was mainly biomass. Wood, fibre, leaves, crops, crop residues, residual food, animal wastes are known as biomass. The advancement of science has led to the discovery of electricity, rendering the demand of fuel manifolds. People could not remain satisfied only with the production of heat and electricity using biomass. Fossil fuels, that is, oil, gas and coal were discovered in order to satisfy the then and future need of resources. Sources of traditional energy are mainly biomass, fossil fuel, nuclear fuel and renewable energy. Uranium is being used as nuclear fuel. Currently, world's 10, 64 and 11 percent energy needs are met using biomass, fossil fuel and nuclear fuel, respectively [4]. Renewable resources like sun, wind, water current and so on provide only $1 \%$ of the total electricity. Hydroelectricity and biomass, considered mostly as renewable resources, are meeting the needs of world energy demand almost equally. On the other hand, a debate for and against using biofuel, which is a form of biomass, is up roaring [9]. There are mainly two sources of biofuel oil producing trees and crops, whose chemical names are bioethanol and biodiesel, which are mainly used in vehicles. Because biofuels are extracted from oil producing trees and crops, they are being blamed for today's world food crisis, the high price of food, and environmental destruction. Another potential sector of biomass, biogas, a never-ending source of debate, is harmless to the environment. These are gases produced by the natural breakdown of wastes from biomass by micro-organisms.

A crisis arises whenever there is a gap between supply and demand. From industrial revolution to 1970, there was not much crisis of oil, and the price was quite stable (3 dollars/barrel). In 1973, oil embargo imposed by the Organization of the Petroleum Exporting Countries (OPEC) on the United States (Yom Kippur war) caused the cost of oil to increase up to 12 dollars, four times its previous price [10]. It was the highest price in the last 150 years. Cost per barrel was below 25 dollars from the 1980s to 2003. However, compared to the expense in 2003, price increased six times in just five years from 2005 to 2009, outperforming the growth of 1973. Cost per barrel in the last five years (20112015) had varied from 100-35 dollar. The price dropped a record low in December 2015 within the last 11 years which is nearly 35 dollar [6]. This is quite unusual due to world's political cum economic instabilities, OPEC's incapability to control over oil production and distribution, USA and other countries more oil production anticipating emerging alternatives to oil and coal. The low price of oil may persist in the next few years. However, oil consumptions at a high rate will cause global warming and energy insecurity in the long run if no alternatives are found. The world needs huge energy specially in the developing countries that result in energy crisis. The main reasons for energy crisis are industrialization, urbanization, inadequate energy policy, regulation, and management, lacking investments, improved quality of life, the enormous demand for oil in the developing countries, a decrease in oil reservoirs, and political distrust in oil supplying countries. The whole world is lost when it comes down to the untamed increase of such an essential substance of our lives. So, it is hard to figure out where the energy demand and supply will stand in the future if no alternative to this crisis is found.

The fact that energy resources are a must to increase the quality of life and salvage the mankind is undeniably true. Energy use per capita has increased hundred times in developed countries since human civilization. It is estimated to increase several times in the future. The world resides about 7 billion people today. Amongst them, about 1.2 billion people are totally deprived of electricity, 2.7 billion people depend on traditional biomass, one-half live in poverty, and at least one-fifth are severely undernourished. The rest live in comparative comfort and health [6]. It is evident that poverty and energy availability are correlated. Energy resources are the key to development. The more fuel a country burns, the more developed it is, and this goes the other way too. For instance, kWh electricity used per capita of Sweden, United States, Japan, Malaysia, India, Pakistan, Sri Lanka, Bangladesh, and Tanzania are 12290, 12954, 7752, $4345,744,452,527,348,165$, respectively $[11,12]$. If the fuels are used up at this rate, oil, gas, and nuclear fuel may disappear in about 50-60 years. Only coal will remain for the next 200 years [5]. However, if coal is used as an alternative, the world's weather and climate will deteriorate even more. Increased global warming and natural disasters will be the aftermath. Because, if we continue to supply this ever increasing rate of fuel consumption, the sea level might increase 1 to 2.5 meter within the next 50 years. As a result, all of the world's lower part will be under water. So, to avoid this 
fuel crisis, search for alternative energy has become a real concern and a challenge for everybody. To control environment pollution and fulfill the huge fuel demand of the world in the future, the world needs to turn towards low-carbon renewable energy technologies. Now the fundamental question comes to the people's mind that how this can be possible? However, too rapid a transition could bring energy shortages that disrupt the industry and have a devastating social impact. In light of the global initiatives, policies and probable alternatives, some suggestions are made to resolve the global energy crisis in the following section.

\section{SUGGESTIONS TO GETTING RID OF GLOBAL ENERGY CRISIS}

Just $0.01 \%$ of the total solar energy available in the countries situated in the tropical regions (Sun Belt) is equivalent to the world's total energy supply. Global use of solar energy is very scanty. This enormous un-used solar energy is not used just because of the lack of technology. Only new technology can bring enough energy supply for the future generations. On the other hand, not today's nuclear technology, only a new nuclear technology can be another source of alternative energy where Figure 2 shows its conceptual schematic diagram. This is the special type of thorium232 based nuclear reactor run by the proton beam accelerator. This is because; today's conventional uranium (U-235) based nuclear technology has four unresolved issues of cost, safety, waste, and proliferation. On the other hand, apart from the conventional nuclear technology meaning thorium (Th232) based nuclear reactor and nuclear fusion reactor could possible to get unlimited energy. Because a sufficient amount of Th-232 is available on today's earth $(20,000$ years $=3 x$ rate of today's fuel consumption). We cannot build nuclear weapons from the combustible fuel of Th-232 nuclear reactors. Above all, Th-232 reactor can produce 40 times more electricity than the conventional nuclear reactors and will create a lot less nuclear waste and the probability of an accident is zero. The fission reaction will be controlled by the emitted neutrons ( $n$ ) from the spallation reactor's high energetic proton beams in the sub-critical thorium reactor given in Eq. 1-2. Spallation reaction takes place when high energetic proton beam strikes with liquid (lead, mercury) or solid target (tungsten, tantalum) [13]. This reaction is akin to fission reaction but different physics. About 20-30 neutrons with high intensity are produced in one spallation reaction whereas 2-3 neutrons are produced in a nuclear fission reaction. These neutrons can be used to maintain criticality of a system which is basically a subcritical system. That is why the scientists have stated it to be energy amplifier, and it could be a novel form of nuclear energy. Its characteristics includes environmentally friendly, zero-emission greenhouse gases, non-proliferating, no long-lived radioactive byproducts, no chance of runaway reactions and a very small fuel inventory.

${ }^{232} \mathrm{Th}+\mathrm{n} \rightarrow{ }^{233} \mathrm{U}$

${ }^{233} \mathrm{U}+\mathrm{n} \rightarrow$ Fission products $+3 \mathrm{n}+$ Heat Energy

R\&D activities for building a thorium reactor as pilot basis have progressed so far. We can hope within the year 2020, it will be implemented [5, 14]. Other potential alternative source of nuclear energy is the Generation III+ evolutionary designs Small Modular Reactors (SMRs).

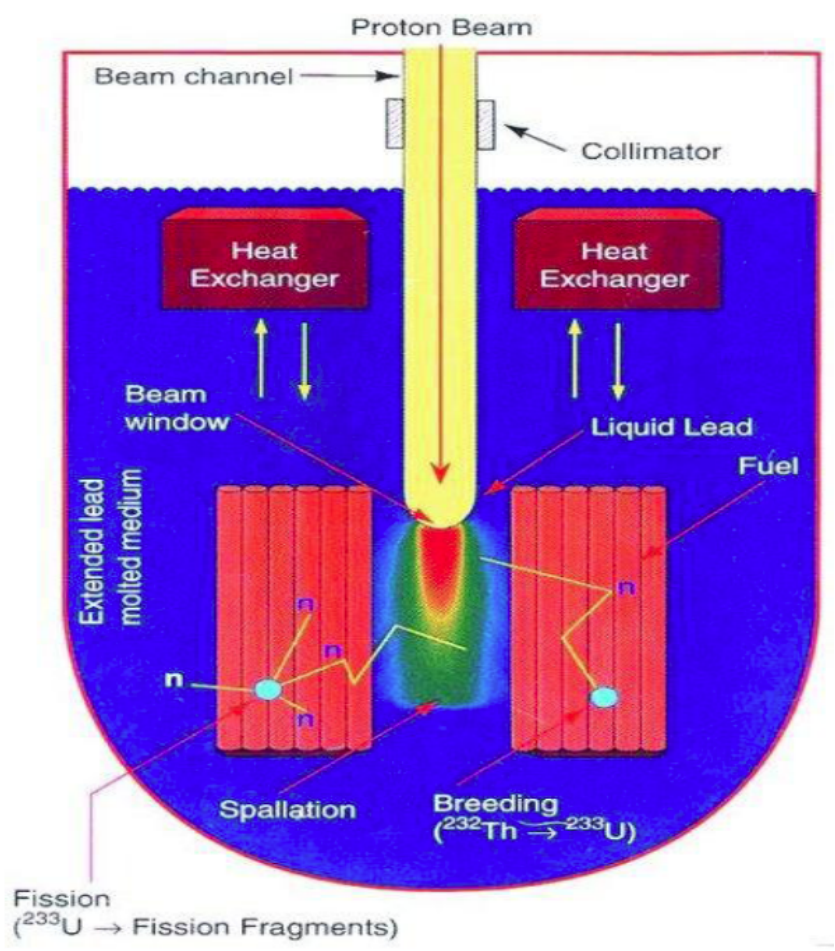

Figure 2: Schematic diagram of the thorium based nuclear reactor run by the Accelerator Driven System [5].

Designed features of the SMRs are more scalable and easier than the traditional nuclear reactors. This type of technology will be one-seventh the capital cost of the traditional reactors and could supply electricity at between one-fourth to one-third of the traditional reactors. They will be proof against core meltdowns, terrorist attacks and any possible scenario that could lead to widespread environmental contamination. SMRs technologies are currently under piloting and 
demonstration stages in China, USA and Europe [15]. Future fuel demand can also be met with the nuclear fusion if today's all scientific research ends successfully. Besides this, there is another potential fuel, hydrogen, which can play a vital role in running automobiles and generating electricity. There are many sources for creating hydrogen. Only efficient and appropriate technology can bring a revolutionary change. It would not be surprising that technologically advanced countries could find serious alternative solutions to coal and oil by 2035 ! Let's start thinking the whole world would generate zero $\mathrm{CO}_{2}$ emission clean energy for all within the next two decades! Electricity history, energy policy, administrative framework for electricity generation, transmission and distribution, energy use, energy crisis, potential energy reserves, perspective electricity generation plan, and then suggestions to get rid of the energy crisis in Bangladesh are presented in Section $\mathbf{5}$.

\section{ENERGY CRISIS IN BANGLADESH}

Bangladesh has been facing acute energy crisis before independence. The first electricity was used on $7^{\text {th }}$ December 1901 during the illumination of the electric lights using a diesel generator at Ahsan Monjil, the Newab of Dhaka [16]. Then the people first got access to electricity in 1928 when some small diesel power units were built at Abdul Gani Road, Dhaka. The first power station was built in 1939 at Hatirpul, Dhaka by a British Company using steam turbine and first electricity Directorate was created in 1948 in order to plan and improve power supply situation. East Pakistan Water and Power Development Authority (EPWAPDA) was established in 1959 giving responsibilities for distribution of water and electricity. After independence in 1971, Bangladesh Power Development Board (BPDB) was established on May 1, 1972, to boost the power sector. Before going into details about the reasons for the energy crisis, background data of the country, energy policy, reforms of power sectors from bundling to unbundling, available energy resources and their limitations, and perspective energy plan are vigorously revisited and updated for a clear understanding of the policymakers, energy experts, and readers. Finally, suggestions are made based on the future fuel availability and technological advancement to get rid of the energy crisis in Bangladesh.

\subsection{Background Information}

Bangladesh is located in South Asia. India borders it on the East, West, and North and by the Bay of Bengal on the South. A small part is also connected with Myanmar. The land is a deltaic plain with a network of numerous rivers and canals. The total area of the country is $1,47,570 \mathrm{~km}^{2}$. Of them, about $17 \%$ is forestry. The country houses a few hilly areas in the South-East and the North-East. Bangladesh is a country of subtropical monsoon climate. There are six seasons in a year. Winter, Summer and Monsoon are the more prominent ones. Winter begins in November and ends in February. In winter, the temperature ranges from a minimum of $7-13^{\circ} \mathrm{C}$ to a maximum of $24-$ $31^{\circ} \mathrm{C}$. In summer, the temperature records in the range of $37-41^{\circ} \mathrm{C}$ or occasionally rises even more. Monsoon begins in July and ends in October. About $80 \%$ of the total rainfall occurs during this period. The population of the country has stood at 159.70 million in 2016 according to the Bangladesh Bureau of Statistics [17, 18]. The population growth rate is $1.3 \%$. The population density is 1,125 inhabitants $/ \mathrm{km}^{2}$ in 2016 . The present literacy rate is $71 \%$, and the life expectancy is about 70 years. The GNI per capita is US\$1,314. The GDP growth rate in the fiscal year of $2014-2016$ is $6.51 \%$. Bangladesh has a per capita energy and electricity consumption of $276 \mathrm{KgoE}$ and $348 \mathrm{kWh}$, respectively, which is one of the lowest in Asia [11, 19]. On the other hand, the global average electricity consumption per capita is $3,064 \mathrm{kWh}$. Only about $59.60 \%$ of its people have access to electricity [19]. More than $70 \%$ of the total population lives in the rural areas. Of them, $15 \%$ have access to electricity, and the rest mainly depends on traditional biomass.

\subsection{Energy Policy}

Bangladesh has an energy policy, a power policy, a natural gas policy, a draft coal policy, renewable energy policy, and a nuclear energy policy [20]. Ministry of Power, Energy and Mineral Resources (MOPEMR) formulated the first National Energy Policy (NEP) in 1996. The prime aim of this NEP is to ensure proper explorations, productions, distributions and rational use of energy sources to meet the growing energy demand of the country. Then the MOPEMR undertook a comprehensive program for updating the NEP in 2005 for realizing the rapid changes of energy use in the global as well as domestic perspectives. Priority is given on diversification of indigenous commercial energy resources, with coal assuming as a potential source in providing the country's future energy needs. Due attention is also given for construction of Nuclear Power Plants (NPPs) as base load plants for fuel diversity. At the same time, the opportunity for cross-border electricity trade is sought to enhance the 
energy security. A long-term strategic plan is required for carrying out systematic exploration and proper appraisal of discoveries of minerals. There is still left unattended activities for exploration of gas and minerals in the offshore and deep sea areas of the country although immense potentiality exits. Realizing the increasing number of consumers, minimizing system losses, attracting investors to invest capital, the Government has started power sectors reforms from bundling to unbundling.

\subsection{Power Sector Reforms: Bundling to Unbundling}

Bangladesh Power Development Board (BPDB) was created in 1972, a public sector organization with the responsibilities for generations, transmissions, and distributions of electricity. It has started its journey with the generation capacity of $200 \mathrm{MWe}$. Due to the tremendous increased number of consumers, BPDB has been unbundled into separate companies responsible for a major portion of power generations and distributions mainly in urban areas except for the capital, Dhaka and West Zone of the country. Electricity distribution for rural areas is given responsibility to the Rural Electrification Board (REB) which was established in 1977as a semi-autonomous Government entity. REB is currently operating the70 rural electric cooperatives under the Palli Bidyuit Samity (PBS). Apart from distribution of electricity, REB has created Rural Power Company Ltd. (RPCL) for generating electricity. As Dhaka housed more population and became a metropolitan city, Dhaka Electric Supply Authority (DESA) was formed in 1991 for taking care of the distribution systems and bringing improvements in customer service, and revenue collection. As a part of reforms and restructuring, Dhaka Power Distribution Company Ltd. (DPDC) a new entity took over DESA activities in 2008 to unite the power system in order to be more competitive, reliable and efficient one. The creation of Dhaka Electric Supply Company Ltd. (DESCO) was also part of the reforms with an aim to reduce the burden of the DPDC responsibilities. An about two-third portion of electricity in major part of the Dhaka city including Narayangonj is under the distribution network of the DPDC. The rest part of the Dhaka city and some parts of the Tongi city are under the distribution network of the DESCO. REB, DPDC, and DESCO are running under the Power Division of the MOPEMR. Beyond these areas, a new power distribution company named West Zone Power Distribution Company (WZPDC) was established in 2003 as a BPDB subsidiary and is responsible for the country's South-West power distribution. Meanwhile, the Power Grid Company of Bangladesh (PGCB) was created in 1996 to own, operate, and expand the national power grid across the country. The PGCB is a subsidiary company of the BPDB and began operation of the transmission systems of the BPDB and DESA since 2003.

Currently BPDB is the only purchaser to purchase electricity from the Independent Power Producers (IPPs). IPPs have been allowed to enter the market since 1996. Several power plants belonging to IPPs supply electricity to the national grid and several others are under constructions. These plants are run by natural gas, oil and represent about $45 \%$ of the country's total electricity generation. Self-generators (captive) with $2,100 \mathrm{MWe}$ capacities supply electricity directly to the consumers. All kinds of IPPs including rentals and quick rentals are running under the BPDB.

The state-owned entities still dominate power generation, transmission, and distribution sectors. However, these sectorsare opened long back to attract the foreign and private entrepreneurs with offering fringe benefits. BPDB generatesabout $55 \%$ of the total electricity in Bangladesh and holding shares almost $99 \%$. The first reform was started through the transformation of BPDB owned Ashuganj Power Station into Ashuganj Power Supply Company Limited (APSCL) in 2003 as an independent company. In a similar way, Electricity Generation Company of Bangladesh (EGCB) and North-West Zone Power Generation Company (NWZPGC) are also formed as the subsidiary companies of the BPDB responsible for electricity generations in Dhaka district and North-West part of the country.

Bangladesh Oil, Gas, and Mineral Corporation (Petrobangla) deals with the commercial sides of the oil and gas sectors and holds the shares of 13 stateowned sister companies involved with oil and gas productions and distributions. One of the sister organizations of Petrobangla, Bangladesh Petroleum Exploration and Production Company (BAPEX) oversees the exploration and production activities of oil and gas. There are two particular companies operating productions, distributions, and explorations of coal and hard rocks (granite, limestone). Another independent organization named Bangladesh Petroleum Corporation (BPC) deals with refining, storage, distribution and import of crude oil and petroleum products. The Government has already committed to ensuring electricity for all by 2021 [21]. Such kind of 
massive reforms from small to smaller organizations for power generation and distribution networks seem unexpected situation and may hinder in realizing the Government vision.

\subsection{Available Energy Resources and their Limitations to Meet the Energy Crisis}

Bangladesh is not blessed with fossil fuels like gas, oil, and coal. Bangladesh had good reserves of natural gas. Coal deposits are situated mainly in deep underground. There is no oil depository and no potential reserves of heavy minerals (uranium, thorium). Bangladesh is only blessed with good sunshine. Except for the sun other renewable energies like wind and hydro are less potential. The available energy sources, probable reserves, and their use considering fossil fuels and renewable categories are summarized briefly in the following Sub-Sections 5.4.1 -5.4 .2 .

\subsubsection{Fossil Fuels}

\section{Natural Gas}

The search for petroleum in Bangladesh started in the 1900s. The exploration, production, transmission and distribution of gas sector began in the 1960s on a limited scale. After independence in 1971 and for rapid economic development of the country, Petrobangla was formed in 1972. Twenty-six (26) gas fields have been discovered until today, and total recoverable proven and the probable gas reserve has been estimated to be at 768 Billion Cubic Meter (BCM). The proven recoverable reserve $(1 \mathrm{P})$ is $588 \mathrm{BCM}$ and the probable recoverable reserve is $180 \mathrm{BCM}$ [22]. Summary of natural gas reserve in Bangladesh is given in Table 1. Up to June 2016, as much as 369BCM gas was produced, leaving only $399 \mathrm{BCM}$ of recoverable gas. Currently, 19 gas fields are in the production stage. Average daily production capacity is 77 Million Cubic Meter (MCM) against the daily demand of $90.61 \mathrm{MCM}$. The demand for gas will increase to $108 \mathrm{MCM}$ per day at the end 2016 . So the daily shortfall is about $28.31 \mathrm{MCM}$. About $70 \%$ of the country's fuel consumption meets from the natural gas. In the fiscal year $2014-15$, about $40.17 \%$ of produced gas is used to generate electricity, followed by industry $16.85 \%$, captive power $17.17 \%$, fertilizer $6.17 \%$, domestic $13.06 \%$, CNG $5.44 \%$, commercial $1.05 \%$ and teaestates $0.09 \%$. The only indigenous limited source of energy of the country is the natural gas, and this has been continuously producing and consuming in significant quantities since 1970 .

$\underline{\text { Oil }}$

Bangladesh has small reserves of petroleum at 26 gas fields. Because of the high level of oil consumptions and small reserves, Bangladesh is known to an oil importer country. Under a Processing Agreement with BPC, Eastern Refinery Limited (ERL) processes crude petroleum products imported by the BPC and deliver the finished petroleum products (Octane, Petrol, Diesel, Kerosene) to their subsidiary companies of BPC for marketing and distributions. From Figure 3, it can be seen; petroleum import has grownup gradually with increasing the fuel cost. Petroleum import needs to be continued at a high rate to meet the high power demands of maintaining the economic growth at $7 \%$ or even more. However, in the PSMP2010, dependency on petroleum products for power generation is given less priority beyond the year 2021 [24]. Priority is given on importing coal and LNG for power generation in meeting the future energy needs. Presently the oil price is a record low which is nearly 30 USD per barrel. This trend may prolong. The Government is taking advantages of the current low oil price to phase-out of fossil fuel subsidies.

$\underline{\text { Coal }}$

Presently, coal meets around $2 \%$ of the total energy mix. To relieve off natural gas dependency, coal is identified as a major fuel option. The reasons are twofold; first, estimated reserves of around 3.2 billion tonnes coal in the Northern regions of the country in the six identified coal fields (Barapukuria, Phulbari, Khalaspir, Dighipara, Jamarganji and Kuchma) and second, cost effectiveness in importing coals from the neighbouring countries. Currently, Barapukuria coal mine is in operation. For this, in the PSMP 2010, 23

Table 1: Summary of Natural Gas Reserve in Bangladesh [22]

\begin{tabular}{|c|c|c|c|c|c|c|}
\hline \multirow[t]{2}{*}{$\begin{array}{l}\text { No. of } \\
\text { field }\end{array}$} & \multirow{2}{*}{$\begin{array}{l}\text { Total Gas Initially } \\
\text { in Place } \\
\text { (GIIP) in BCM }\end{array}$} & \multicolumn{3}{|c|}{$\begin{array}{c}\text { Recoverable reserve } \\
\text { (Billion Cubic Meter-BCM) }\end{array}$} & \multirow{2}{*}{$\begin{array}{l}\text { Cumulative } \\
\text { production }\left(30^{\text {th }}\right. \\
\text { June } 2016 \text { in } \\
\text { BCM) }\end{array}$} & \multirow{2}{*}{$\begin{array}{l}\text { Remaining } \\
\text { reserve }(2 P)\left(1^{\text {st }}\right. \\
\text { July } 2016) \text { in } \\
B C M\end{array}$} \\
\hline & & $\begin{array}{l}\text { Proved } \\
\text { (1P) }\end{array}$ & $\begin{array}{c}\text { Proved + } \\
\text { Probable(2P) }\end{array}$ & $\begin{array}{l}\text { Proved+ Probable+ Possible } \\
\text { (3P) }\end{array}$ & & \\
\hline 26 & 1104 & 588 & 768 & 887 & 369 & 399 \\
\hline
\end{tabular}




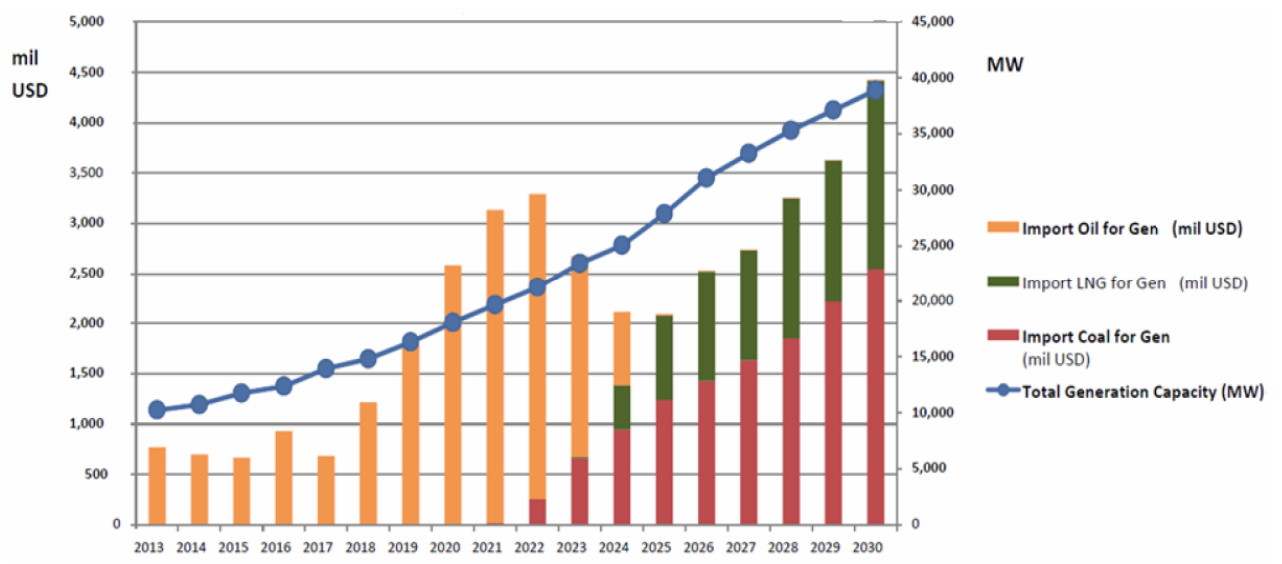

Figure 3: Trend of rising import fuel cost for power generation: [22, 31].

coal-fired power plants are projected both in public and private sectors totalling about $20,000 \mathrm{MWe}$ by 2030 as shown in Figure 3. The fuel mix forecasted for 2030 shows over $50 \%$ dependence on coal where $30 \%$ on domestic and $20 \%$ on import coal. Considering the present status of domestic coal, implementation of those projects solely depends on import coal. The total coal requirements would be approximately 60 million tonnes per year. Handling this massive volume of import coal will require a deep port, rail transport, and coal stocking infrastructure. However, there is only one on-going deep-sea coal terminal project in Matarbari Island and another two at Maheskhali and Payera are in planning stage.

\subsubsection{Renewables}

\section{Biomass}

Biomass refers to biological material from living or recently living organisms. It consists of plants or plant wastes, animal wastes. Biomass includes cattle dung, agricultural residues, poultry dropping, wood, wood wastes, straw, water hyacinth, rice husk, sugar cane and many others byproducts from a variety of agricultural processes. It is the primary sources of energy in Bangladesh as the country is based on agriculture. Biomass has a large contribution in the total primary energy consumption of Bangladesh. More than $85 \%$ of the rural population mainly depends on biomass for cooking, crop drying, and winter heating.

\section{Biogas}

Biogas typically refers to a gas produced by fermentation of organic matters including cattle dung, sewage sludge, municipals solid wastes, biodegradable wastes, poultry droppings, etc. This is another derivative from biomass. Nowadays, biogas production plays an important role for mitigating energy crisis since the necessary resources are easily and cheaply available everywhere. The Government and several NGOs are working together for power generation from biogas. About 34,400 biogas plants are generating approximately $5 \mathrm{MWe}$ electricity across the country. These plants are used for lighting, cooking, and heating of the rural households. Many more biogas plants are under construction and in planning stages.

\section{Hydroelectricity}

The country's only hydroelectric power plant under BPDB is the Karnafully Hydropower Station with 230 MWe capacities. BPDB is considering increasing its generation capacity up to $330 \mathrm{MWe}$. There is no other potential site found until today for construction of hydroelectric power plants in the country.

\section{Solar Energy}

Bangladesh is situated in the tropical climate zone that brings enormous opportunity to use solar energy almost over the year. The daily average solar radiation varies from 4-6.5 $\mathrm{kWh} / \mathrm{m}^{2}$ with maximum radiation available in March-April and minimum in DecemberJanuary. Except few days in the rainy season, the sun appears all day for about 10 hours. Applications of solar energy have found potential not only for lighting solutions but also for irrigation and heating purposes. Solar power home systems and mini off-grid systems in rural areas are found competitive with other sources. Government funded Infrastructure Development Company Limited (IDCOL) supports Non-Government Organizations (NGOs) for installing Solar Home Systems (SHSs). Total 4 million SHSs with approximately $150 \mathrm{MWe}$ capacities in the rural areas were installed till December 2016 [25]. In addition, hundreds of roof-top and several grid-tied solar power systems are running in the urban areas. A good 
number of off grid solar power systems and 193 solar irrigation pumps are also running in the rural areas of the country. To meet the target of electricity generation from renewables as per PSMP 2010, a good number of solar power plants and solar irrigation pumps with various capacities at different locations of the country are under construction, and many more are under planning. There are presently nine companies assembling solar panels using imported solar cells [26, 27]. Some R\&Ds are going on a pilot basis to develop the cost-effective Generation 1 solar cells for adopting advanced solar cell technologies in the country [28].

\section{$\underline{\text { Wind }}$}

A few studies with the help of the international organizations were conducted to explore the potentiality of wind energy, particularly along the country's $724 \mathrm{~km}$ long coastline. Some studies have found that wind energy can cost-effectively generate more than 2,000 MWe electricity in the coastal regions. Harnessing wind energy in the underdeveloped and coastal areas of the country is the only hope for those communities. These isolated communities will never be connected to the national grid. Presently a few number of wind power projects with about $2 \mathrm{MWe}$ generation capacity are running with the help of the Government as well as NGOs in the coastal belt. The development of wind energy technologies will be crucial for Bangladesh to achieve its national vision of providing electricity to all by 2021 [29]. However, there is a lacking of adapting cost-effective wind energy technology in the country.

\section{Nuclear}

Bangladesh is not blessed with heavy minerals. Recent studies have found some potential reserves of uranium and thorium in the coastal belt. However, due to technical limitations, these minerals are not extracted commercially although economic potentiality exists. Peaceful applications of nuclear energy were initiated in the early 1960's under the Pakistan Atomic Energy Commission (PAEC). After independence in
1971, Bangladesh became a Member of the International Atomic Energy Agency (IAEA) in 1972. Bangladesh Atomic Energy Commission (BAEC) was formed in 1973 with the goal of peaceful applications of nuclear science and technology for national development. BAEC has been operating the $3 \mathrm{MW}_{\mathrm{th}}$ TRIGA MK-II nuclear research reactor since 1986. The research reactor is used for manpower training, radioisotope productions, and research purposes [4].

The Law on Nuclear Safety and Radiation Control was enacted in 1993 and given the sole regulatory responsibilities of the BAEC for the enforcement of the atomic law for peaceful applications of nuclear energy in the country. Rising demands of nuclear research, industrial applications, and power generation, a separate regulatory organization named Bangladesh Atomic Energy Regulatory Act (BAERA) was formed on 12 February 2013. The main objective of the BAERA is to strengthen the legal framework related to nuclear safety and radiation safety specially in all stages of licensing and inspection of nuclear facilities and ionizing radiation sources [4]. Bangladesh is evolving an energy-mix diversification, where nuclear energy is assumed as one of the potential sources to meet the growing energy needs. Bangladesh has signed an Inter-Governmental Agreement with the Russian Federation in 2009 to set up two nuclear power reactors in Rooppur, the North-Western part of the country. The clear intention is to meet the high volume of energy demands by the country's emerging industrial and socio-economic development sectors. According to the agreement, the Russian Federation will construct the two nuclear power plants (VVER-similar to world PWR) having a capacity of 1,250 MWe each, supply fuels for their lifetime, take back spent fuels, and provide training for safe operation and maintenance of the reactors and other scientific and technical engagement. Table $\mathbf{2}$ shows the Russian VVER nuclear reactor, its electric capacity, expected construction year and commercial operation. Furthermore, the Government has also given instructions to the BAEC for looking suitable sites in the

Table 2: Plan for Nuclear Power Plants in Bangladesh [4]

\begin{tabular}{|c|c|c|c|c|}
\hline Station/Project name & Type/model & $\begin{array}{c}\text { Electric } \\
\text { capacity (MW } \mathbf{e})\end{array}$ & Expected construction time & $\begin{array}{c}\text { Expected } \\
\text { commercial } \\
\text { operation time }\end{array}$ \\
\hline \hline Rooppur Nuclear Power Plant (Unit-1) & $\begin{array}{c}\text { VVER } \\
\text { (AES 2006) }\end{array}$ & 1250 & By 2016 & By 2023 \\
\hline Rooppur Nuclear Power Plant (Unit-2) & $\begin{array}{c}\text { VVER } \\
\text { (AES 2006) }\end{array}$ & 1250 & One year after the first unit & By 2024 \\
\hline
\end{tabular}


Southern part of the country for the establishment of nuclear power plants to the next. Implementation of nuclear power project takes 7-10 years for the newcomer countries as it requires massive infrastructure, trained workforce, and billions of dollars to finance.

Now it is clearly depicted about the availability and potentiality of the conventional and renewable energy resources in Bangladesh. However, it is worthwhile to compare and contrast about the Levelized Cost of Electricity (LCOE) generation with the available energy resources in order to access electricity for all at an affordable cost.

Table 3 shows the various energy sources, their reserves and LCOE generations. The LCOE is calculated considering the capital cost, fuel cost, operation and maintenance cost, and plant life performances $[28,30]$. The plant life for thermal power plants (gas, oil, coal) and renewables (hydro, wind, solar) is considered for 20-30 years while the plant life for nuclear power is considered for 60 years. Generally the cost of generation is at least $60 \%$ higher than the present retail cost in Bangladesh. The people who are enjoying grid electricity at the cost of $60 \%$ subsidy are the lucky segment of the society. Subsidy creates social injustice and should be avoided in general.

\subsection{Perspective Energy Plan}

Ministry of Power, Energy, and Mineral Resources (MOPEMR) had prepared the Power System Master Plan 2010 [24] in September 2010. According to the PSMP 2010, different energy mixes had been considered to achieve the total demand of electricity nearly 10,000 MWe by $2016,23,800$ MWe by 2021 and 38,600 MWe by 2030 [24, 31]. Detailed plan of the energy mix with different sources is given in Table 4. It was seen that the Government had installed about $11,877 \mathrm{MWe}$ electricity in 2016 against the total demand of $10,618 \mathrm{MWe}$. There was still needed for about 1,000 MWe in 2016. Natural gas was used as the major source of energy which was about $62 \%$ over the total energy mix in 2016. Electricity generation using gas by 2021 and 2030 has been shifted from $62 \%$ to $25 \%$ due to anticipating a shortage of renewed gas supply. However, generation of electricity using coal will be increased $2 \%$ to $50 \%$ by 2030 . The Government wants one-third $(20,000 \mathrm{MWe})$ of the country's power to be generated with coal by 2030 . This would be difficult to achieve due to the uncertainty of huge coal supply, constraints for infrastructure development, vibrant energy policy, and bureaucratic bottleneck. Contributions of renewables over the energy mix will be achievable nearly $3 \%$ although it was stated $5 \%$ by 2015 and $10 \%$ by 2020 in the PSMP 2010 [24]. Nuclear power will contribute about $10 \%$ of the total energy mix by 2021 and by 2030 as per PSMP 2010. This will also be difficult to achieve. It might be possible to get $2,400 \mathrm{MWe}$ electricity generations $(6 \%)$ from nuclear by 2030 if everything goes well. It has been identified in the PSMP 2010 that about $7.5 \%$ electricity over the total energy mix will be achievable by importing from the neighboring countries. The PSMP changes every five years, and it is prudent to gift us a knowledgeable and attainable PSMP for the country's 7\% economic growth. Table 5 shows the installed capacity both under construction and planning stages as of June 2016

About 7,749 MWe installed capacity from gas, coal, oil, nuclear, and renewables is presently under construction and 6,093 MWe installed capacity is now under planning stage. Electricity generation using imported Liquefied Natural Gas (LNG) is termed as a challenging issue in the country's perspective energy plan as it requires infrastructure and capital. Based on

Table 3: Energy Sources, Reserves and Levelized Cost of Electricity (LCOE) Generation in Bangladesh as of 2015 [22, 23]

\begin{tabular}{|c|c|c|}
\hline Sources of energy & Reserve & LCOE (Cent/kWh) \\
\hline \hline Coal & 3.2 billion tons & $7.7-10.25$ \\
\hline Natural gas & $425 \mathrm{BCM}$ & 6.4 \\
\hline Oil & 12 million barrels as condensates in 26 gas fields & $10-23$ \\
\hline Hydro & $330 \mathrm{MW}$ & $23-32$ \\
\hline Solar & Infinite $\left(1000 \mathrm{~W} / \mathrm{m}^{2}\right)$ & 20 \\
\hline Wind & Coastal belt, $724 \mathrm{~km}$ long & $10-11$ (predicted) \\
\hline Nuclear & Nil & 10 \\
\hline
\end{tabular}


Table 4: Suggested Energy Mix in the Perspective Plan during 2015-2021-2030 [24, 31]

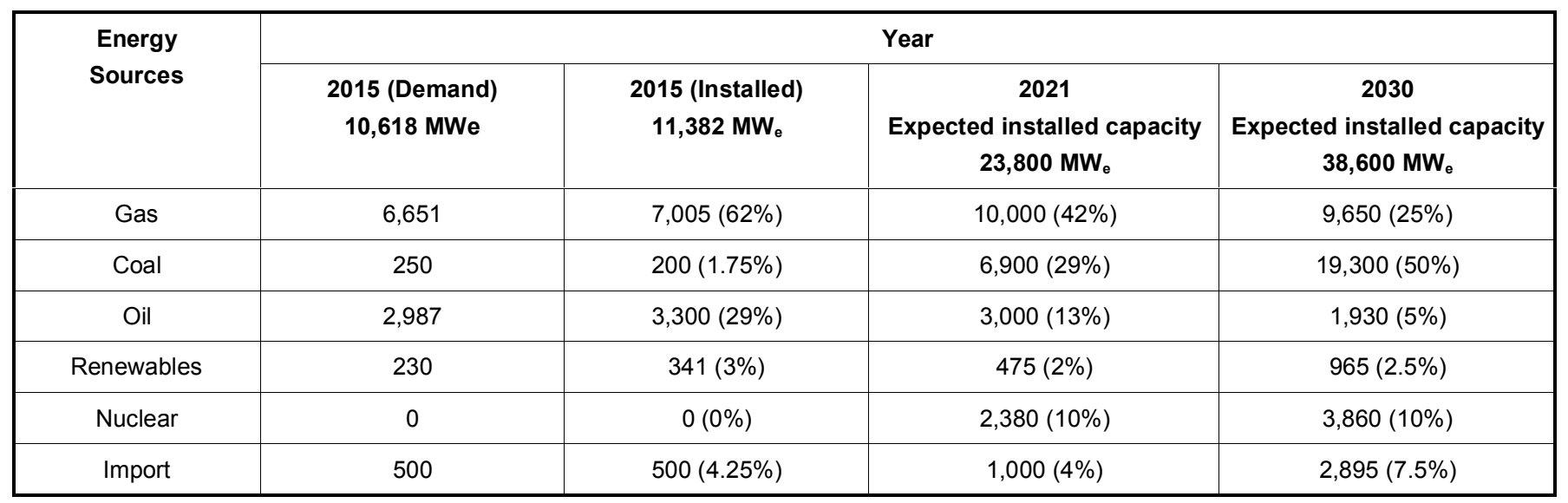

Table 5: Electricity Generation Enhancement Program as of June 2016 [31]

\begin{tabular}{|c|c|c|}
\hline Fuel type & $\begin{array}{c}\text { Under construction } \\
\left(\mathbf{M W}_{\mathbf{e}}\right)\end{array}$ & $\begin{array}{c}\text { Under planned } \\
\left(\mathbf{M W}_{\mathrm{e}}\right)\end{array}$ \\
\hline \hline Natural gas & 2,107 & 3,101 \\
\hline Oil (HFO, HSD, Diesel) & 1,096 & 6,500 \\
\hline Coal & 2,645 & 150 \\
\hline Renewables (solar, biogas) & 8 & 100 \\
\hline Renewables (wind) & - & $2,000 \mathrm{MW}_{\mathrm{e}}$ \\
\hline Nuclear & $2,000 \mathrm{MW}_{\mathrm{e}}$ & 225 \\
\hline LNG & 0 & 26 \\
\hline
\end{tabular}

the available energy resources and then country's perspective energy plan as per the PSMP 2010, some suggestions are made for resolving the energy crisis in the following Section.

\section{SUGGESTIONS TO GETTING RID OF ENERGY CRISIS IN BANGLADESH}

The historical GDP growth from 1994-2004 was a little over $5 \%$. The GDP growth solely depends on the energy consumption per capita of her total population. The GDP growth rate was $6.50 \%$ in the year 2015 2016 against the achieved base load of 9,047MWe [32]. In order to keep continuing the GDP growth rate at $6.5 \%$ or even higher in the successive years and ensuring electricity for all by 2021 , the total demand of $23,800 \mathrm{MWe}$ needs to be supplied in a cost-effective and sustainable manner.

Bangladesh is suffering from fuel crisis since her birth. The crisis is getting worse day by day. It is also obvious that substantial amount of energy is used inefficiently due to system loss and corruption. The reasons for energy crisis are due to lack of sustainable energy policy, energy regulations, in-country experts, reliable technology, best practices, and investments. It is impossible to supply future demand by either using today's technology or today's habit of energy culture among the people. Stocked gas will be finished within the next 10-15 years. Coal is the only available fuel today. Coal though can be considered an alternative but cannot be the only option fuel due to the shortage of gas or unavailability of oil to generate electricity. Because we lack the technology to extract coal without upsetting the nature and in a way that's economically profitable. Therefore, preparation of a final coal policy is critical. In order to continue and renewed operation of the gas-based power plants, secured gas supply through regional pipelines/ importing LNG/exploring gas fields in the offshore is equally important. This is because importing coal as well as LNG storage and transition facilities requires major investments that would require years to complete and billions of dollars to finance.

Progress and prospects of renewable energy, i.e., hydro, wind, biomass, biogas are very limited in 
Bangladesh. However, solar energy is very much prospective both in the on-grid and off-grid areas, despite the record high growth in SHSs $(50,000-60,000$ installations per month) particularly in the off-grid areas. It has only been possible to get about $150 \mathrm{MWe}$ of electricity from 4 million SHSs. Other potential applications of solar energy in the grid connected urban areas are solar rooftop, solar minigrid, and solar thermal. If all grid connected electric and diesel run irrigation pumps could be replaced by solar power, it could save about $8,000 \mathrm{MWe}$ of electricity. If feed in tariff can be introduced to independent solar power producers, more investments will be looking forward.

In this case, the nuclear power plant can be a potential source [8]. We already have the experiences of 29 years of managing and maintaining the nuclear research reactor since 1986 [4]. We now need to select the right technology in order to build a nuclear power plant and thus gain experiences first hand. Development of infrastructure, effective nuclear regulation, need based human resources development plan and quick adoptability of nuclear technology is the key to successful implementation of the nuclear power projects. By using our experience, later on, there would be no restriction in implementing theTh-232, SMRs or fusion reactor and ensuring long-term safety of fuels and waste management. Now, we need to tackle the fuel crisis by taking long-term planning with particular concern on conventional and other alternative energy sources like solar, wind, regional, and/sub-regional grids. Cross-border electricity trading has now shown us attractive as well as cost-effective. Energy diplomacy among South-East regions for both conventional and renewables needs to get more important focus of Bangladesh [33]. In this regard, country's energy policy and regulation should be cohesive with the South-Eastregions. Government needs to convince the international donor organizations for capital in the power sectors. Strong R\&D efforts with the Government support should be carried out to develop energy efficient technologies by academicians and researchers. It also needs to introduce energy audit to be practiced as compulsory via regulation to all industries [34]. Energy audit can be a tool of the energy culture which is the similar concept like the safety and security cultures in the nuclear industries $[35,36]$. Developing energy culture in people's belief and attitudes can save a substantial amount of energy from industry to domestic areas. We also need to teach how to conserve and convert energy efficiently by introducing academic programs on energy engineering in all levels of educational institutions in order to make ample energy experts and aware every one. Otherwise, the hope of dealing with today's crisis or supplying future demand of electricity will stay in the dark [37].

\section{Conclusions and Policy Implications}

Electricity is the most preferred form of energy. It needs accessibility, affordability, and sustainability. To meet the energy needs of 7 billion people, it would not be wise to heavily depend on fossil fuels as these will not last forever. New dominant sources are required to meet the huge energy demands, specially in the developing countries, with an acceptable climate impact due to the earth's induced warming up. If energy supply breaks down, mankind may suffer enormous consequences. This study can be summarized as follows:

(1) Conventional energy reserves, sustainable energy policy and regulation, investments for developing innovative energy technologies and explorations of new energies are found to be the main impediments for getting continued and renewed quality energy.

(2) Extension of more energy networks is very important to ensure homogeneous energy distributions in the South-East and the Middle East Asian countries for increasing the quality of life.

(3) On an average about one-third of the total electricity generation takes place globally by burning coal. If the North America, Europe, China and India would reduce generating electricity from coal and oil in order to move towards a low carbon and clean energy use, the world would face a serious energy crisis. For this, efficient alternative energy sources need to be developed prior hand. Neither today's nuclear technology nor solar technology can replace. However, completely new revolutionary technologies, such as thorium-based nuclear technology, SMRs, fusion technology, and renewable energy technologies, specially Generation II-III solar technologies and cost effective carbon storage devices must be available commercially which are the main goals of the Paris climate change accord COP21.

(4) Like Bangladesh and other energy hunger countries need to be in-line with the global 
energy strategies by taking policy intentions for adopting innovative energy technologies based on the COP21 outcomes, forming wider regional energy networks, developing ample energy experts if peak demand wants to be met.

The technically advanced countries should come forward to modify drastically the present traditional energy generation, distribution, and consumption patterns considering vast, urgent, and innovative R\&Ds. Innovative solutions obviously require long time R\&Ds and huge capitals. Therefore, it is of vital importance to working technically and economically advanced countries together under a common platform without any late. Apart from this conclusion, specific recommendation is provided for the development of an appropriate energy culture model by the researchers to intensify the global energy saving programs. Understanding the importance of the energy culture model by the policymakers, energy practitioners, energy traders, and consumers can be the alternative future energy pathways.

\section{RECOMMENDATION}

Belief and attitude towards energy saving are the most efficient source of energy generation and can limit $\mathrm{CO}_{2}$ emissions at large. These kinds of habits can be more appropriately called as "energy culture". Energy culture can be the assembly of characteristics, attitudes, and behaviours of individuals, organizations, and institutions which serves as a means to support and enhance energy saving programs. Energy economics, energy-extravagant, energy efficiency, and energy audit can be the appropriate indicators for forming the energy culture model. Development of a suitable energy culture model based on variable indicators and then verification of this model using the technical guidance on self-assessment methodologies (to be developed) is of paramount importance and can be the potential source of energy savings. By applying the self-assessment tools for evaluation of the energy culture at facilities using surveys, interviews, document reviews, and observations can justify the necessity for the development of an energy culture model.

\section{HIGHLIGHTS}

- Evolution of various energy resources, their reserves, and usages are discussed.

- $\quad$ Alternative technologies are revisited and their prospects are analyzed for addressing energy crisis.
- Developing an energy culture model to raise awareness among the mass people is essential to save more energy.

- $\quad$ Re-thinking current energy policy for adopting emerging and alternative technologies is needed.

\section{REFERENCES}

[1] California Energy Commission. Energy Story. 1994-2012, Available from: http://www.energyquest.ca.gov/story/ accessed 12.06.2016.

[2] Robert HT. A History of the Growth of the Steam-Engine. UK: Oxford University Press 1939.

[3] Bellis M. The History of the Automobile 2006. Available from: http://inventors.about.com/library/weekly/aacarsgasa.htm/(ac cessed 24.08.2016).

[4] Islam MS. Pormanur Shaktter Jana-Ojana (in Benguli) Nuclear Energy: Known and Unknown Facts (in English). 1st Edition. Dhaka: Mullick and Brothers 2015.

[5] Rubbia C. Does Nuclear Energy have Any Future? Keynote Paper Presented in the ICTP. Italy, 17 October, 2005.

[6] World Energy Outlook. WEO.IEA. 2015. Available from: http://www.iea.org/ (accessed 15. 07.2016)

[7] Times of India. Electricity right.Madras High Court. 2013. Available from: http://timesofindia.indiatimes.com/ india/Electricity-supply-is-a-legal-right-Madras-high-courtsays/articleshow/23841025.cms (accessed 26.08.2016).

[8] Clark P. Climate Deal: Carbon Dated? The Financial Times Ltd. UK. 15 December 2015.

[9] Kavangh E. Looking at Biofuels and Bioenergy. Science 2006; 312: 1743-8.

[10] Oil Crisis. Yom Kippur War. 1973, Available from: http://www.mediander.com/connects/244180/1973-oilcrisis/\#!/34276/yom-kippur-war/ (accessed: 21.08.2016)

[11] Global Economy. Bangladesh Energy Use per Capita. Available from: http:/www.theglobaleconomy.com/ Bangladesh/Energy_use_per_capital (accessed 15.08. 2016).

[12] World Bank. Electricity Power Consumption (kWh per capita).WB. Available from: Data.worldbank.org/indicator/ EG.USE.ELEC.KH.PC/(accessed 26 .08. 2016).

[13] Islam MS, Terada A, Kinoshita H, Hino R, Monde M. Analytical Study of Narrow Channel Flow for a Spallation Target System Design.Technical Report. Japan Atomic Energy Research Institute (JAERI). JAERI-Tech 2001044.P.1- 49. 2001.

[14] OECD. Accelerator Driven Systems (ADS) and Fast Reactors (FRs) in Advanced Nuclear Fuel Cycles, A Comparative Study.NEA.2002.Available from: http://www. nea.fr/html/ndd/reports/2002/nea3109.html/(accessed 15.07.2016).

[15] World Nuclear Organization. Small Modular Reactors. SMRs. WNO, Available from: http://www.world-nuclear.org/info/ Nuclear-Fuel-Cycle/Power-Reactors/Small-Nuclear-PowerReactors/(accessed 15.08. 2016).

[16] Power Division. National Electricity Observation Week Brochure. Ministry of Power, Energy and Mineral Resources (MOPEMR), Government of the People's Republic of Bangladesh. 10-12 December, 2015.

[17] Bangladesh Bureau of Statistics. BBS, Available from: http://www.bbs.gov.bd/(accessed 26.01.2016).

[18] Worldometers. Bangladesh Population. Available from: http://www.worldometers.info/world-population/bangladeshpopulation/ (accessed 26 .08. 2016). 
[19] Matin MA. Prospect of a SAARC Power Grid.South Asian Journal 2015; 13: 67-5.

[20] National Energy Policy. NEP. Ministry of Power, Energy, and Mineral Resources (MOPEMR). Government of the People's Republic of Bangladesh, 2008. Available from: www.powercell.gov.bd/ (accessed 10.08. 2016).

[21] Planning Commission. Perspective Plan of Bangladesh: 2010-2021. Making Vision 2021 A Reality. Government of the People's Republic of Bangladesh, April 2012.

[22] PETROBANGLA. Report on the Issue of Gas Production, Bangladesh Oil, Gas and Mineral Corporation (in Bengali). MOPEMR. Bangladesh 2015.

[23] Hydrocarbon Unit. Annual Report Gas Production Distribution and Consumption. MOPEMR, Bangladesh 2014-2015.2015.

[24] Power Division. Power System Master Plan (PSMP) 2010. Ministry of Power, Energy, and Mineral Resources. MOPEMR. Government of the People's Republic of Bangladesh 2011.

[25] IDCOL. Projects and Programs: Renewable Energy. 2016, Infrastructure Development Company Ltd., Dhaka: Bangladesh.

[26] Islam MS, Hasan MR. Study of Performance Evaluation, Economic, and Environmental Impact of $1.68 \mathrm{kWp} \mathrm{DC}$ Operated Submersible Centrifugal Solar Pump with Autotracker Using Low Cost DAS. Int Journal Environment and Sustainable Development 2016; 15(2): 146-158.

[27] Islam MS, Hasan MR, Mohammadi F, Majumdar A, Ahmad Ali. Manufacturing Techniques of Low-Cost Si-based Crystalline Type Solar Cell in Bangladesh. Journal of Mechanical Engineering. Transaction of the Mechanical Engineering Division. The Institution of Engineers 2012; 42(1): $29-7$.
[28] Islam MS. Solar Electricity: Achievements and Expectations. Article Published in the Daily Benguli News Paper. Jugantor. Dhaka. 22 May. 2012. Available from: www.jugantor.com/ (accessed 12 7.2012).

[29] Ullah MH, Hoque T, Hasib MM. Current Status of Renewable Energy Sector of Bangladesh and a Proposed Grid Connected Hybrid Renewable Energy System. International Journal of Advanced Renewable Energy Research. 2012; 1(11): 618-627.

[30] Rahman A. Controversy over the RNPP Energy Cost. Energy \& Power Magazine. 13.17 February, 2016.

[31] BPDB. Report on the Issue of Increase in Power Tariff. MOPEMR. Bangladesh 2015.

[32] Unnayan Onneshan, Energy Security: Trends and Challenges: Bangladesh Economic Update. Bangladesh 2014.

[33] Rahman AAKM. Energy Diplomacy of Bangladesh: Exploring Potentials, Paper Presented at Int. Conf. on Energy Security Plus: Relevance of Japanese Experience, Organized by BIISS in Collaboration with Japan Foundation. Dhaka. October 28-29, 2015.

[34] Islam MA. Energy Audit and Its Impact in Bangladesh. Paper Presented in the Seminar on Prospect of Energy Audit and Alternative Energy to Meet in the Present Energy Crisis in Bangladesh. Military Institute of Science and Technology. Dhaka. October 9, 2010.

[35] IAEA. Educational Programme in Nuclear Security. Nuclear Security Series No.12. Vienna, Austria. 2010.

[36] IAEA. TECDOC. Safety Culture in Nuclear Installations. Guidance for Use in the Enhancement of Safety Culture. No.1329. Vienna. Austria 2002.

[37] Lior N. Energy Resources and Use. The Present Situation and Possible Paths to the Future. Energy 2008; 33: 842-857. 